\title{
RESULTS OF SURGICAL TECHNIQUES APPLIED IN BLEPHAROPTOSIS
}

\author{
Ozturk Yucel, ${ }^{1}$ Ayyıldız Taha, ${ }^{2}$ Ozgur Rodop Ozlen, ${ }^{3}$ Oral Yesim, ${ }^{3}$ Kocabas Seyhan ${ }^{3}$ \\ ${ }^{1}$ University of Health Sciences Haydarpasa Education and Research Hospital, \\ Department of Ophthalmology, Istanbul, Turkey \\ ${ }^{2}$ Bursa City Hospital, Department of Ophthalmology, Bursa, Turkey \\ ${ }^{3}$ University of Health Sciences Dr. Lutfi Kırdar Kartal Education and Research Hospital, \\ Department of Ophthalmology, Istanbul, Turkey
}

Primljen/Received 02. 09. 2019. god.

Abstract: Objective: Our aim was to analyze the success rates of patients who underwent levator aponeurosis or frontal suspension with silicone tube surgery due to blepharoptosis according to the elevator function (LF) and to compare our results with the literature.

Material and Methods: We included twenty-five eyes of 47 patients who had levator aponeurosis or frontal suspension with silicone tube surgery in this study. The patients were grouped as good, moderate, and poor according to their LF. Good and moderate patients had levator aponeurosis while poor patients had frontal suspension with silicon tube surgery. The follow-up period after surgery was 2 to 36 months. The results were evaluated with margin reflex distance (MRD) which greater than $2 \mathrm{~mm}$ was considered as successful, between 1 and $2 \mathrm{~mm}$ was satisfactory, and less than $1 \mathrm{~mm}$ was unsuccessful. Also, patients required revision surgery was considered as unsuccessful.

Results: Twenty-nine (61.7\%) men and 18 (38.3\%) women with a mean age of 35.16 years (range $=0-84$ years) were included in this retrospective study. Thirteen cases $(27.7 \%)$ had bilateral, and 34 cases had unilateral ptosis(72.4\%). Eight of the 13 patients with bilateral ptosis had bilateral and 5 of them had unilateral surgery. Blepharoptosis was due to congenital $(60.0 \%)$, aponeurotic $(19 \%)$, traumatic $(1.8 \%)$, Horner's syndrome (1.8\%) and myotonic dystrophy $(1.8 \%)$. The preoperative mean MRD value was $0.56 \pm$ $0.85 \mathrm{~mm}(0-3 \mathrm{~mm})$. The levator function (LF) was poor in 18 eyes $(32.7 \%)$, moderate in 9 eyes $(16.4 \%)$ and good in 28 eyes (50.9\%). Thirty-seven patients $(67.3 \%)$ underwent levator aponeurosis, and 18 patients had frontal suspension with silicon tube surgery. In our postoperative controls, 33 patients were consid-
Prihvaćen/Accepted 10. 10. 2019. god.

ered as successful. Three patients were considered as satisfactory, and one patient was considered unsuccessful.

Discussion: Levator aponeurosis and frontal suspension with silicone tube surgeries are both effective surgical methods to treat ptosis. Postoperative success is positively affected by determining the surgery method, according to LF. Our results showed that elevator aponeurosis surgery is more satisfying in good and moderate cases, and frontal suspension with silicone tube is best in poor cases.

Key words: ptosis, surgical, techniques.

\section{INTRODUCTION}

Blepharoptosis or ptosis is the lower than normal position of the upper eyelid, which vertically narrows the palpebral space. Treatment is usually surgical. Blepharoptosis is a cosmetic and functional disorder that causes even psychosocial problems. The cause, quantity and levator function are important in determining the surgical method to be selected. The correct diagnosis is decisive for the success of the treatment. The diagnostic categories of ptosis are scheduled as pseudoptosis, congenital, and acquired ptosis. Acquired causes include mechanical, myogenic, neuromuscular, neurogenic, and cerebral. Generally, two basic methods are applied: frontal muscle sling and levator surgery. Levator aponeurosis surgery is preferred in cases with good and moderate levator function, and frontal suspension surgery is preferred in cases with poor levator function.Müllerectomy and similar methods can be used in mild ptosis. The frontal suspension technique is a surgical method used in cases of blepharoptosis whe- 
re the function of the levator palpebra muscle is insufficient. This surgery is preferred in congenital myogenic blepharoptosis, blepharophimosis syndrome, oculomotor nerve paralysis, Marcus-Gunn blepharoptosis, chronic progressive ophthalmoplegia (1-4).

We aimed was to classify the patients with blepharoptosis according to their LF and to apply frontal suspension with silicone tube or levator aponeurosis surgery methods to treat this problem and to compare our surgical results with the literature.

\section{MATERIAL AND METHODS}

Fifty-five eyes of 47 patients who underwent levator aponeurosis and frontal suspension with silicone tube surgery due to blepharoptosis were included in our study.Our study was conducted at the University of Health Sciences Kartal Training and Research Hospital Eye Clinic between January 2011 and June 2015. Classification of blepharoptosis type was made according to the findings obtained from anamnesis, examination, and operation.

Preoperative evaluation included visual acuity, anterior and posterior segment examinations, eye movements, and strabismus examination, Bell's phenomenon, jaw-winking phenomenon, eyelid line-height, LF and margin reflex distance (MRD) measurements. The degree of the blepharoptosis was determined according to the MRD and the LF. Additional ocular, systemic diseases were investigated. Patients were assessed with the MRD and asymmetry between the two eyelids in the post-operative period. Post-operative complications were also recorded. Patients with blepharoptosis were examined in three groups as good, moderate, and poor according to the LF. We used the LF as the main factor to decide the surgical method to be applied. If the $\mathrm{LF}$ was $<5 \mathrm{~mm}$, it was evaluated as poor, $5-9 \mathrm{~mm}$ as moderate and $>10 \mathrm{~mm}$ as good. In patients with good and moderate LF, levator aponeurosis surgery and cases with poor LF had frontal suspension with silicon tube surgery. The effectiveness of the operation was evaluated in patients who were followed between 2 months and 36 months after surgery.

The efficacy of the surgery was evaluated in the post-surgical examination. Participants with MRD greater than $2 \mathrm{~mm}$ were considered successful, between 1 and $2 \mathrm{~mm}$ were considered satisfactory, and below $1 \mathrm{~mm}$ were considered unsuccessful. In addition, patients who required revision surgery were considered unsuccessful. The number of revision surgery, patient satisfaction, overcorrection, inadequate correction, and other complications were found for evaluating the surgical results.

The operation was performed under local anesthesia in adult patients with good cooperation. In patients who did not want to undergo a procedure with local anesthesia, pediatric patients were operated under general anesthesia.

\section{RESULTS}

Twenty-nine (61.7\%) male and 18 (38.3\%) female patients aged between 0 to 84 years (mean age 35.16 years). Ptosis was bilateral in 13 cases $(27.7 \%)$ and unilateral in 34 cases $(72.4 \%)$ including 17 right eyes and 17 left eyes. Eight of the 13 patients with bilateral ptosis were bilateral, and 5 had unilateral surgery (Table 1). Patients were followed between 2 months and 36 months (mean 15 months) after surgery.

Blepharoptosis causes of the 55 patients were congenital (\%60.0), 19 aponeurotic (\%34.5), traumatic (\%1.8), Horner's syndrome (\%1.8), and myotonic dystrophy (\%1.8). Three patients had strabismus, and four patients had amblyopia. Three patients had previously undergone penetrant keratoplasty. One of the congenitally categorized patients had third cranial nerve palsy (Table 2).

Table 1. The Gender of the Patients and the Affected Eye

\begin{tabular}{|c|c|c|}
\hline & $n^{*}$ & $\%$ \\
\hline \multicolumn{3}{|l|}{ Gender } \\
\hline Female & 18 & 38.3 \\
\hline Male & 29 & 61.7 \\
\hline \multicolumn{3}{|c|}{ Affected Eye } \\
\hline Right & 17 & 36.2 \\
\hline Left & 17 & 36.2 \\
\hline Bilateral & 13 & 27.1 \\
\hline
\end{tabular}

n: Number of patients, \%: percentage

Table 2. Types of Ptosis

\begin{tabular}{|l|c|c|}
\hline & $\mathbf{n}^{*}$ & $\mathbf{\%}$ \\
\hline Congenital & 33 & 60 \\
\hline Aponeurotic & 19 & 34.5 \\
\hline Traumatic & 1 & 1.8 \\
\hline Horner syndrome & 1 & 1.8 \\
\hline Myotonic dystrophy & 1 & 1.8 \\
\hline
\end{tabular}

n: Number of the patients, \%: percentage

MRD values were found to be minimum $0 \mathrm{~mm}$, maximum $3 \mathrm{~mm}$ (mean $0.56 \pm 0.85 \mathrm{~mm}$ ) on preoperative examination in the cases. Preoperative LF of the cases was $0 \mathrm{~mm}$ minimum, maximum $16 \mathrm{~mm}$ (mean 8.58 $\pm 4.45 \mathrm{~mm})$. The LF in the eyes was evaluated as poor in $18(32.7 \%)$, moderate in $9(16.4 \%)$ and good in 28 $(50.9 \%)$ cases (Table 3 ). 
Table 3. Preoperative Levator Function (LF)

\begin{tabular}{|l|c|c|}
\hline \multicolumn{1}{|c|}{ LF } & n & \% \\
\hline Poor & 18 & 32.7 \\
\hline Moderate & 9 & 16.4 \\
\hline Good & 28 & 50.9 \\
\hline
\end{tabular}

$\mathrm{n}$ : Number of the patients, \%: percentage

Thirty-seven patients (67.3\%) underwent levator aponeurosis, and 18 patients had frontal suspension with silicon tube surgery. In postoperative controls 46 $(83.6 \%)$ cases were successful, $7(12.7 \%)$ were satisfactory, and $2(3.6 \%)$ cases were unsuccessful. Revision surgery was performed on 2 cases that were accepted unsuccessful. Margin reflex distance (MRD) patients who undergone levator aponeurosis surgery was minimum $0 \mathrm{~mm}$, maximum $3 \mathrm{~mm}$, mean $(0.780 .94$ $\mathrm{mm}$ ) preoperatively. Preoperative LF of the cases was a minimum $7 \mathrm{~mm}$, a maximum $16 \mathrm{~mm}$ (mean 11.29 2.47). The LF in patients with levator aponeurosis surgery was moderate in 9 eyes $(16.4 \%)$ and good in 28 eyes $(50.9 \%)$.

MRD values of the cases with frontal suspension with silicone tube surgery were minimum $0 \mathrm{~mm}$, maximum $1 \mathrm{~mm}$, average $0.11 \pm 0.32 \mathrm{~mm}$. The preoperative levator function of these cases was minimum $0 \mathrm{~mm}$, maximum $4 \mathrm{~mm}$, mean $3.00 \pm 0.97$. At the last follow-up after levator muscle surgery, 33 (89.2\%) were successful, $3(8.1 \%)$ were satisfactory, and $1(2.7 \%)$ was unsuccessful.

In the last follow-up, frontal suspension surgery with silicone band 13 were $(72.2 \%)$ successful, four patients were (22.2\%) satisfactory, and one patient was $(5.6 \%)$ unsuccessful (Table 4).

Two patients were accepted as unsuccessful in the evaluation after surgery. One of the unsuccessful patients underwent levator aponeurosis, and the other underwent frontal suspension with silicone tube surgery.

Table 4. Results of the Surgeries

\begin{tabular}{|l|c|c|}
\hline \multicolumn{1}{|c|}{ Levator Aponeurosis Surgery } & n & \% \\
\hline Successful $^{*}$ & 33 & 89.2 \\
\hline Satisfactory** & 3 & 8,1 \\
\hline Unsuccessful*** & 1 & 2,7 \\
\hline
\end{tabular}

\begin{tabular}{|l|r|c|}
\hline Frontal Suspension with Silicone Tube & $\mathbf{n}$ & $\mathbf{\%}$ \\
\hline Successful* & 13 & 72.2 \\
\hline Sat2sfactory*** & 4 & 22,2 \\
\hline Unsuccessful*** & 1 & 5,6 \\
\hline
\end{tabular}

$\mathrm{n}$ : Number of the patients, $\%$ : percentage, successful $*$; MRD $\geq$ $2 \mathrm{~mm}$, satisfactory **; MRD 1-2 mm, unsuccessful ***; MRD $\leq 1 \mathrm{~mm}$
These unsuccessful patients had revision surgery. No additional postoperative complications were observed.

\section{DISCUSSION AND CONCLUSION}

Blepharoptosis is a problem that often seen in ophthalmology clinics and treated with surgery. It is both a functional and aesthetic problem for the patient. When adults have more cosmetic problems in the preliminary plan, amblyopia, which can develop due to the prevention of visualization in the pediatric age group, is a special consideration. Variable factors in the formation of ptosis and anatomical differences between individuals may cause unexpected results at the end of the surgery. The success of the surgical procedure depends on the amount of ptosis, the etiology, and the good evaluation of levator muscle function before surgery. Although the clinical and anatomical characteristics of blepharoptosis are well assessed, the differences in the normal anatomy of the eyelids, the diversity of the etiopathogenesis of the disease, and the coexistence of different pathologies in some cases make the surgery relatively difficult and reduce the success rate (5-8).

Ptosis surgery success rates have increased with new methods developed in recent years. These methods include frontal suspension, transconjunctival resection, levator resection, levator aponeurosis surgery, aponeurosis repair, levator advancement, and aponeurosis (4).

Blepharoptosis may have different etiologies. It may be congenital or acquired according to the age of onset. At first evaluation, pseudoptosis and ptosis should be distinguished. Ptosis is the inadequate openness of the upper eyelid when there is no problem in the levator muscle. Bulbi, enophthalmos, hypotropia, dermatochalasis can cause fitizis. In these patients, it is more appropriate to consider surgical treatment of ptosis if necessary after the treatment of underlying scarring (such as orbital or strabismus surgeons) before deciding on ptosis surgery.

The application of ptosis surgery in adulthood allows the surgeon to perform local anesthesia. Thus, during operation, the patient can be brought to a sitting position, and the eyelid height can be adjusted during surgery. The fact that the visual acuity remains closed during infancy and early childhood is known to lead to amblyopia with sensory deprivation.

Congenital ptosis is associated with visual dysfunctions such as amblyopia, strabismus, and refractive errors. The highest prevalence was revealed for myopia with $30.2 \%$ (95\% CI 3.0-69.8\%), followed by $22.7 \%(95 \% \mathrm{CI} 18.5-27.8 \%)$ for amblyopia, $22.2 \%$ (95\%CI 7.8-63.1\%) for astigmatism, $19.6 \%(95 \% \mathrm{CI}$ 16.5-23.2\%) for strabismus, $17.3 \%$ (95\% CI 13.1-22.9\%) 
for anisometropia and $4.0 \%$ for hyperopia $(95 \% \mathrm{CI}$ $1.8-7.1 \%$ ) (8). While population-based studies focused on the prevalence of amblyopia have reported a prevalence varying from $0.74 \%$ to $5.6 \%$ depending on ethnic group, in a study by Oral et al. on 83 eyes of 72 patients, they observed the frequency of amblyopia in congenital ptosis patients by $48 \%(10,11)$.

Patients with ptosis are examined in three groups as good, moderate, and weak according to levator muscle function. The basal examinations of the eyelid, such as measurement of preoperative levator muscle function, MRD and palpebral opening, should be carefully evaluated. Traditionally, patients with poor levator function are treated with frontal suspension with sling surgery, while patients with good levator function are undergoing levator aponeurosis surgery. The results of levator aponeurosis resection in patients with moderate to good levator function are quite encouraging. Thus we preferred levator aponeurosis surgery in cases of good and moderate levator function.

Today, unlike classical levator resection, levator muscle surgery is intervened only in levator muscle aponeurosis, but Muller's muscle, which helps upturning of the lid and Whitnall ligament supporting the eyelid, is not performed. Thus, goblets, meibomian, and assisted lacrimal glands, which stabilize tears during surgery are not damaged. In this view, dry eye symptoms such as burning and stinging after surgery are less frequent.

Although there is a consensus on the use of the frontal suspension method in cases where the levator function is poor (less than $4 \mathrm{~mm}$ ), there is no standard practice for the suspension materials. For the hanging, the autogenous fascia lata is considered as the best material with the least risk of infection, absorption, and rupture. Non-autogenous primary materials are; fascia, skin, muscle and sclera grafts, silicone strip, supra mid, silk, polyester sutures, expanded polytetrafluoroethylene (gore-tex) (12).

We used silicone strips as suspension material because we did not need to prepare the fascias for frontal suspension surgery, so it would reduce the case length and allow the cover height to be adjusted again. Levator aponeurosis surgery is a method applied to the levator muscle itself without interfering with Müller's muscle, tarsal ve conjunctiva.

Because of the easier recognition of anatomic structures, more resection of the tissues, and the possibility of advancing to the tars, the approach through the skin in levator aponeurosis surgery is more preferred than the conjunctival approach (13). Ünal et al. reported that $62(83.7 \%)$ successful and $8(10.8 \%)$ satisfactory $4(5.4 \%)$ poor outcomes were found in this series of 74 eyes (7). Özay and colleagues also performed le- vator aponeurosis in 24 eyes of 21 patients and found that in cases with aponeurotic ptosis $(93.4 \%)$ were successful, and $6.7 \%$ were satisfactory (14). Beden and colleagues achieved results in successful 17 (89.4\%) cases and satisfactory in $2(10.6 \%)$ cases in levator aponeurosis surgeries (6).

Older reported that they were successful in $95 \%$ of, 113 patients with aponeurotic ptosis (15). As seen in the above studies, levator surgery results are good in patients with good levator function. In our series, levator aponeurosis with good and intermediate levator muscle function is similarly good. According to our postoperative control, $89.2 \%$ of the patients who underwent levator muscle surgery were successful, and $8.1 \%$ were found to be satisfactory.

In our study, we preferred frontal suspension surgery in patients with poor levator muscle function.

Ali et al. reported that eyebrow strap with fascia lata is a safe and effective technique for correcting weak levator-function ptosis (16).

Many surgeons have searched for alternatives that can be used in place of the fascia lata because of taking the time frontal suspension technique with autogenic fascia lata, the difficulty of obtaining the autogenous fascia lata, the inadequate length of the material under three years of age and scarring of the leg. Tillett initially described the use of the silicone strip in the frontal suspension in 1966 (17).

Carter et al. using silicone strips, reported 0-31.8\% recurrence of ptosis, and 4-5\% uncovered (18). Unal et al. reported that $61.9 \%$ of the patients who applied silicone band with frontal hanging were successful, 14.3\% had a satisfactory result, and $23.8 \%$ of cases had recurrent ptosis (19).

In the postoperative follow-up period of $72.2 \%$ of the patients we used silicone tape as frontal sling material, we found that the surgery was successful. We found satisfactory results in $22.2 \%$ of cases and poor in $5,6 \%$ of cases. With these results, the success rate of the silicone tube and frontal suspension surgeries are similar to the success rates in the literature. Common complications of levator muscle surgery are; lagophthalmic keratitis, infection, entropion, ectropion, scar formation, contour disturbance, conjunctival prolapse, hematoma, and loss of eyelashes.

In the frontal suspension surgery, the suspension material may come out, and infection, pyogenic granuloma development, and eyelash ptosis may occur. Also, recurrent ptosis may develop more frequently in these patients. Özdal et al. detected complications after levator surgery such as conjunctival prolapse in $5 \mathrm{ca}-$ ses, lagophthalmic keratitis in one case, valve hematoma in 5 cases, and minimal openness of the lid during sleep in 3 cases (5). Bayramlar et al. reported that slight 
asymmetric cover line or irregular contour in 7 eyes of 27 eyes, and conjunctival prolapse in 1 eye when performing levator augmentation (20).

In studies with long follow-up periods, the repetition of ptosis is reported at higher rates. In a study conducted by Wilson et al., the success rate of the surgery with prolonged follow-up was reduced in the series of frontal suspension surgery with fascia lata. At the 2-3 years follow-up, the success rates were $90 \%$, and this ratio decreased to $50 \%$ in 8 th and 9th years $(21)$.

Especially in childhood surgeries, patients and their relatives should be informed that additional surgery may be needed. In our cases, after levator aponeurosis surgery and frontal suspension surgeries, a total of two patients were evaluated as poor and revision surgery was performed. When all the patients were assessed, one patient had prolapsing in the lid skin and temporary lagophthalmos in one patient who had levator aponeurosis surgery. No further complications were observed in the controls. After the frontal suspension surgery.

When ptosis surgery is planned, it is very important to determine the correct surgical method to be applied to the patient. Levator muscle surgery for those who have good and moderate muscle function and frontal suspension surgery for those who have poor muscle function are most appropriate. As seen in our series, when surgery is planned according to muscle function, very successful results are obtained. Silicone tapes are safe materials for use in the frontal suspension surgery procedure applied to patients with poor levator muscle function.

\section{Abbreviations \\ LF - levator function \\ MRD - margin reflex distance}

Financial Disclosure and Conflict of Interest: We affirm that we have no financial affiliation (including research funding) or involvement with any commercial organization that has a direct financial interest in any matter included in this manuscript. There were no sources of grant support for this study.

\section{Licensing}

This work is licensed under a Creative Commons Attribution 4.0 International (CC BY 4.0) License.

\title{
Sažetak
}

\section{REZULTATI HIRURŠKIH TEHNIKA PRIMENJENIH U LEČENJU BLEFAROPTOZE}

\author{
Ozturk Yucel, ${ }^{1}$ Ayyıldız Taha, ${ }^{2}$ Ozgur Rodop Ozlen, ${ }^{3}$ Oral Yesim, ${ }^{3}$ Kocabas Seyhan ${ }^{3}$ \\ ${ }^{1}$ University of Health Sciences Haydarpasa Education and Research Hospital, \\ Department of Ophthalmology, Istanbul, Turkey \\ ${ }^{2}$ Bursa City Hospital, Department of Ophthalmology, Bursa, Turkey \\ ${ }^{3}$ University of Health Sciences Dr. Lutfi Kirdar Kartal Education and Research Hospital, \\ Department of Ophthalmology, Istanbul, Turkey
}

Cilj: Naš cilj je bio da analiziramo stopu uspešnosti kod pacijenata koji su bili podvrgnuti operaciji aponeuroze levatora ili frontalnoj suspenziji sa silikonskim tračicama u odnosu na funkciju elevacije i da uporedimo naše rezultate sa literaturom.

Materijal i metode: U ovu studiju smo uključili dvadeset i pet očiju 47 pacijenata koji su imali operaciju aponeuroze levatora ili frontalnu suspenziju sa silikonskim tračicama. Pacijenti su grupisani kao dobri, umereni i loši shodno funkciji levatora. Dobrim i umerenim pacijentima je rađena operacija aponeuroze levatora, dok je kod loših rađena frontalna suspenzijia sa silikonskim tračicama. Period praćenja nakon operacije bio je od 2 do 36 meseci. Rezultati su evaluirani u odnosu na rub kapka-refleks distance (MRD) i smatrani su uspešnim ukoliko je MRD veća od $2 \mathrm{~mm}$, zadovoljavajući ako je između 1 i 2 mm i neuspešnim ako je manja od $1 \mathrm{~mm}$.
Rezultati: U ovu retrospektivnu studiju uključeno je $29(61,7 \%)$ muškaraca i $18(38,3 \%)$ žena, srednje životne dobi od 35,16 godina (0-84 godine). Trinaest slučajeva $(27,7 \%)$ imalo je bilateralni oblik, a 34 slučaja jednostranu ptozu $(72,4 \%)$. Osam od 13 pacijenata sa obostranom ptozom imalo je bilateralnu operaciju, a 5 njih je imalo jednostranu operaciju. Blefaroptoza je bila kongenitalna $(60,0 \%)$, aponeurotska $(19 \%)$, traumatska $(1,8 \%)$, kod Hornerovog sindroma $(1,8 \%)$ i miotone distrofije $(1,8 \%)$. Srednja postoperativna vrednost MRD bila je $0.56 \pm 0.85 \mathrm{~mm}(0-3 \mathrm{~mm})$. Funkcija levatora bila je loša kod 18 očiju (32,7\%), umerena kod $9(16,4 \%)$, i dobra kod 28 očiju (50,9\%). 37 pacijenata $(67,3 \%)$ je podvrgnuto operaciji aponeuroze levatora, a 18 pacijenata imalo je frontalnu suspenziju sa silikonskim tračicama. U našim postoperativnim kontrolama, postignuti rezultati su bili uspešni kod 33 pacijenta, zadovoljavajući kod 3 i neuspešni kod 1 pacijenta. 
Diskusija: Operacija aponeuroze levatora i frontalna suspenzija sa silikonskim tračicama su obe efikasne hirurške metode za lečenje ptoze. Na postoperativni uspeh pozitivno utiče izbor hirurške metode $u$ odnosu na funkciju levatora. Naši rezultati su pokaza-

\section{REFERENCES}

1. Kaynak, P. Pitozis Cerrahisinde Secenekler. Turkiye Klinikleri Ophthalmology-Special Topics. 2018; 11(2): 21-31.

2. Gul A, Duran M, Can E, Niyaz L, Beden Ü. Frontalis suspension materials for the treatment of blepharoptosis: clinical results. Kafkas J Med Sci. 2016; 6(1): 14-7.

3. Yadegari, S. Approach to a patient with blepharoptosis. Neurol Sci. 2016; 37(10): 1589-96.

4. Kusbeci T, Yavas G, Polat O.Evaluation of surgical results in patients with blepharopytosis. Turkiye Klinikleri J Ophthalmol. 2015; 24(1): 29-34.

5. Ozdal PC, Goka S, Teke MY, F2rat E. Levator surgery in the treatment of pitosis. Turkiye Klinikleri J Ophthalmol. 2001; 10: 139-45.

6. Beden U, Sullu Y, Gungor İU, Sayım İ, Erkan D. Results of external levator aponeurosis surgery in blepharoptosis. Turk J Ophthalmol. 2005; 35(3): 265-70.

7. Unal M. Levator aponeurosis surgery. Turkiye Klinikleri J Ophthalmol. 1997; 6: 98-105.

8. Jordan DR,Anderson RL. The aponeurotic approach to congenital ptosis. Ophthalmic Surg. 1990; 21(4): 237-44.

9. Wang Y, Xu Y, Liu X, Lou L, Ye J. Amblyopia, strabismus and refractive errors in congenital ptosis: a systematic review and meta-analysis. Sci Rep. 2018; 8(1): 8320.

10. Zhang JY, Zhu XW, Ding X, Lin M, Li J. Prevalence of amblyopia in congenital blepharoptosis: a systematic review and Meta-analysis. Int J Ophthalmol. 2019; 12(7): 1187-93. li da operacija aponeuroze levatora je sa boljim rezultatima kod dobrih i umerenih slučajeva, a frontalna suspenzija sa silikonskim tračicama je najbolja kod loših slučajeva.

Ključne reči: ptoza, hirurške tehnike.

11. Oral Y, Ozgur OR, Akcay L, Ozbas M, Dogan OK. Congenital ptosis and amblyopia. J Pediatr Ophthalmol Strabismus. 2010; 47(2): 101-4.

12. Can İ, Can B, Konkuralp Y, İnan Y, Kural G. Ptosis surgery with mersilene mesh sling material. T Klin J Ophthalmol. 1995; 4: 184-8.

13. Cakmak SS, Unlu K, Caca I, Bilek B. Anterior approach in levator resection in congenital ptosis. Dicle Med J. 2004; 31:4.

14. Ozay S, Ersoy G, Onder F. Results of levator aponeurosis surgery in patients with blepharoptosis. Turk J Ophthalmol. 2002; 32(6): 809-18.

15. Older JJ. Levator aponeurosis surgery for the correction of acquired ptosis. Ophthalmology. 1983; 90(9): 1056-9.

16. Ali F, Khan MS, Sharjeel M, Din ZU, Murtaza B, Khan A. Efficacy of brow suspension with autogenous fascia lata in simple congenital ptosis Pak J Med Sci. 2017; 33(2): 439-42.

17. Tillett CW, Tillett GM. Silicone sling in the correction of ptosis. Am J Ophthalmol. 1966; 62(3): 521-3.

18. Carter SR, Meecham WJ, Seiff SR. Silicone frontalis slings forthe correction of blepharoptosis: indications and efficacy. Ophthalmology. 1996; 103(4): 623-30.

19. Unal M, Bozan E, Konuk O, Hasanreisoglu B. Choice of frontalis suspension material: ten-years experience, Turk $\mathrm{J}$ Ophthalmol, 2005; 35(3); 271-9.

20. Bayramlar H, Borazan M, Hepşen İ, Daglıoglu MC, Y1lmaz H. Levator Strengthening Surgery Results in Ptosis Strengthening. MN Ophthalmology. 2004; 11(2): 173-8.

21.Wilson M, Johnson RW. Congenital ptosis: long-term results of treatment using lyophilized fascia lata for frontalis suspension. Ophthalmology. 1991; 98(8): 1234-7.

\section{Correspondence to/Autor za korespondenciju:}

Yücel Öztürk M.D.

T1bbiye Cad. No: 2334668

Üsküdar/İstanbul 34668, Turkey

Phone: +90 5320513993

E-mail: yucellozturk@yahoo.com 